\title{
A OBRA, O CONCEITO E O HOMEM: HANS ULRICH GUMBRECHT E A "PRODUÇÃO DE PRESENÇA"
}

\author{
Hans Ulrich Gumbrecht \\ Doutor pela Universidade de Konstanz (Alemanha) \\ Professor Emérito de Literatura na Stanford University
}

Entrevistado por:

Thales Sant'Ana Ferreira Mendes

Mestrando em Letras - Literatura Brasileira - pela Universidade do Estado do Rio de Janeiro (UERJ) thales.sanfer@hotmail.com

Hans Ulrich “Sepp” Gumbrecht (Wuerzburg, 1948-), Professor Emérito ocupante da cadeira de Literatura de Albert Guérard nos Departamentos de Literatura Comparada e de Francês e Italiano na Stanford University, é também afiliado ao Departamento de Culturas Ibéricas e Latino-Americanas, ao Departamento de Estudos Alemães e ao Programa em Pensamento e Literatura Modernos. Suas pesquisas abordam aspectos de literaturas românicas (sobretudo francesa, italiana e brasileira), mas também alemã, além de focar na tradição filosófica ocidental, especialmente a francesa e alemã dos séculos XIX e XX, e nas experiências cotidianas do século XXI - uma obra, em suma, bastante ampla, que transita entre várias disciplinas das humanidades e tem importante repercussão no meio acadêmico. Professor visitante em instituições como Collège de France, PUC-Rio, Universidade de Lisboa e University of Manchester, detentor de dez doutorados honorários em diversas universidades pelo mundo e de um extenso conjunto teórico. Seu livro mais famoso no Brasil é Produção de presença: o que o sentido não consegue transmitir (2010), embora conte com outros igualmente admiráveis, como Modernização dos sentidos (1998), Em 1926 - Vivendo no limite do tempo (1999), Elogio da beleza atlética (2006), Nosso amplo presente - o tempo e a cultura contemporânea (2015) e Depois de 1945: latência como origem do presente (2014). Cheio de gentileza e solicitude, o professor Gumbrecht - que passava uma temporada no Brasil em função do curso de inverno “'Prosa do mundo': a obra de Diderot como periferia do lluminismo (e nosso presente como universo de contingência)", que ministrou na Fundação Casa de Rui Barbosa - nos cedeu uma parte de seu tempo disponível para responder às perguntas abaixo. 


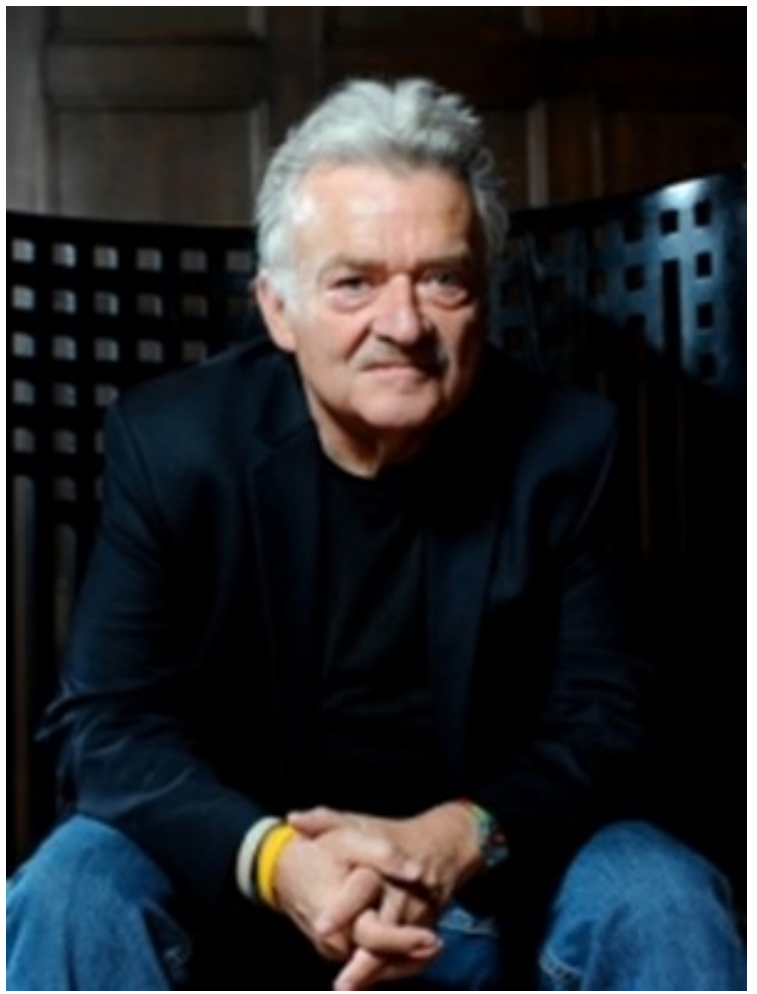

\section{PALIMPSESTO}

1) Production of presence é provavelmente seu trabalho mais conhecido não apenas aqui no Brasil mas, possivelmente, no mundo acadêmico em geral. Para além disso, é também um conceito, fortemente associado ao nome do senhor. Hoje, passada mais de uma década do lançamento da obra, como o senhor analisa essa associação imediata entre conceito e autor? 0 que teria feito o conceito se destacar sobre as demais articulações do conjunto de sua produção teórica?

\section{HANS ULRICH GUMBRECHT}

De uma forma geral e num nível bem menor, eu experimentei aquilo do que Foucault falou uma vez: a associação obsessiva de um conceito ("presença", no meu caso) com o nome de um autor pode ter um forte efeito de repetição, no sentido de que eu sou 
constantemente pedido para retomar pensamentos que eram novos para mim quinze anos atrás (Produção de presença foi publicado primeiramente em inglês em 2004). Mas eu também tenho de admitir que essa "síndrome de presença" parece me acometer com frequência também: assim, primeiro eu acho que finalmente tenho um novo conceito, uma nova questão ou preocupação (stimmung ${ }^{1}$, por exemplo, ou "latência") e depois percebo que esses conceitos aparentemente "novos" têm, na verdade, uma relação genealógica com "presença". De modo geral, minha tendência é antes escapar da "presença" do que cultivá-la ainda mais.

\section{PALIMPSESTO}

2) Olhando para o panorama teórico da época em que ele foi formulado, como o senhor analisa hoje a contribuição trazida pelo conceito de "produção de presença"?

\section{HANS ULRICH GUMBRECHT}

Para ser honesto, fico bastante surpreso e satisfeito de ver que a ressonância tem sido surpreendentemente vigorosa. "Presença" parece ter se tornado parte do horizonte conceitual dentro das humanidades, em mais nenhum lugar, acredito eu, do que no Brasil.

\section{PALIMPSESTO}

\footnotetext{
${ }^{1}$ Palavra alemã para "disposição; estado de espírito; humor".
} 
3) Novos conceitos não surgem do acaso. Foucault, em $A$ ordem do discurso, alertava que os discursos são constantemente originários e devedores de outros discursos, mesmo quando não se tem consciência disso. 0 senhor mesmo, em suas obras, aborda - valor da aprendizagem com o conhecimento do passado. Como o senhor, particularmente, enxerga a inserção de sua obra em determinadas linhagens teóricas e sua filiação a certos autores e correntes filosóficas? Em suma, que influências essenciais o senhor destacaria no processo de criação do conceito de "produção de presença"?

\section{HANS ULRICH GUMBRECHT}

Sem dúvida alguma (e isto deveria ser bem visível no livro), Heidegger - o Heidegger depois da "virada" ${ }^{2}$ - foi a influência e a inspiração mais marcante para mim. Mais precisamente: uma leitura específica de Heidegger (e eu nunca saberei - nem me importo muito - se ele teria concordado comigo), segundo a qual o "ser" representa a "coisa em si mesma" que Kant havia tentado eliminar da tradição filosófica ocidental. A importância que Heidegger teve para mim em hipótese alguma implica uma cegueira quanto ao seu (atestado biograficamente) nazismo. É difícil, mas nós temos de viver com o fato de que um dos maiores pensadores do século XX esteve perto da mais abjeta ideologia. Hoje, acredito eu, a inspiração desse "segundo" Heidegger explica, parcialmente, por que eu quero ser parte do retorno a posições mais "realísticas" na filosofia e na epistemologia.

\section{PALIMPSESTO}

\footnotetext{
${ }^{2}$ No original alemão, "die Kehre”, também traduzido como “a viragem”.
} 
4) Pesquisadores são constantemente movidos por um impulso que os força a buscar inovações que contribuam para seu campo de pesquisa. Como surgiria a necessidade de se criarem novos conceitos?

\section{HANS ULRICH GUMBRECHT}

Para evitar tons heroicos nesta resposta: meu impulso pela inovação vem, acima de tudo, de uma convergência entre tédio (eu fico facilmente entediado quando tenho de repetir coisas) e ambição (é importante para mim ser lido, discutido, criticado).

\section{PALIMPSESTO}

5) O senhor diria que a criação de novos conceitos ou releituras são sempre necessárias? Haveria momentos (ou casos) em que a procura por renovação teórica seria apenas artificial, com vistas à mera criação de polêmicas?

\section{HANS ULRICH GUMBRECHT}

Talvez eu preferiria dizer que, de certo ponto de vista, a criação de novos conceitos nas humanidades nunca é "necessária". O mundo exterior à academia (infelizmente, mas claramente) pode viver sem nossas contribuições. Dentro das humanidades, contrariamente, pode-se dizer que a inovação é necessária para manter o movimento intelectual vivo. Acho difícil (talvez impossível), no entanto, realizar uma reivindicação sistemática das melhores ou piores "inovações". Boas são aquelas que encontram ressonância e mudam o cenário conceitual e epistemológico. 


\section{PALIMPSESTO}

6) Não é raro que inovações teóricas venham de encontro a instituições e correntes que busquem perpetuar certas tradições, resultando em resistência e desconfiança. Para o senhor, é ainda possível falar em impactos nos estudos literários gerados por novos conceitos? Como eles, de maneira geral, podem abalar as estruturas de uma tradição crítica?

\section{HANS ULRICH GUMBRECHT}

Como poderiam as inovações não encontrar tal resistência? Isto, acredito, é o caso para qualquer tipo de instituição; há sempre uma tensão, às vezes até uma luta, entre transformação e inércia. E não temos motivo algum para reclamar disso.

\section{PALIMPSESTO}

7) Olhando de forma ampla para as literaturas e sua difusão no espaço escolar, e pensando-se em termos de democratização do saber acadêmico, qual seria a importância da apropriação de novos conceitos no contexto escolar e cotidiano? Haveria métodos úteis para se atingir semelhante objetivo?

\section{HANS ULRICH GUMBRECHT}

Não acredito em "métodos" que possam garantir atenção e ressonância para novas ideias produzidas nas humanidades - e se eles existissem, eu provavelmente não 
os usaria porque acho qualquer forma de "autopromoção" nesse sentido muito embaraçoso. Nós, com efeito, trabalhamos debaixo de posições bastante privilegiadas para produzir novas ideias, novos argumentos e conceitos - e não deveríamos tentar controlar sua recepção e ressonância. Em meu caso, creio já ter encontrado tal ressonância fora da instituição acadêmica, que ocorreu com meu livro Elogio da beleza atlética [In Praise of Athletic Beauty], como uma proposta de compreensão dos esportes como um objeto de experiência estética.

\section{PALIMPSESTO}

8) Uma vida dedicada à pesquisa científica passa por muitas intempéries alheias à vontade do pesquisador, uma vez que a instituição acadêmica é também espaço de confrontos políticos e sociais. Para o senhor, do ponto de vista das relações de poder existentes nesse meio e da distribuição de capital simbólico, que fatores impediriam a disseminação, reconhecimento e mesmo aplicação de certos conceitos na área de Teoria Literária?

\section{HANS ULRICH GUMBRECHT}

Sempre tive a suspeita de que encontrar "resistência" ou mesmo "repressão" da parte dos poderes políticos é um sonho que muito de nossos colegas estão sonhando porque isto significaria que os políticos estariam nos levando a sério - e mesmo nos temendo. Porém, é o contrário que é a verdade: eles normalmente não estão interessados no que estamos escrevendo e fazendo. A única resistência que eu, pessoalmente, encontrei veio de dentro da academia. A editora que lançou a versão 
original de Produção de presença temia que o livro pudesse provocar alguma resistência da parte da "desconstrução", um discurso filosófico popular e dominante na época.

\section{PALIMPSESTO}

9) Mestres sempre têm algo para transmitir a seus discípulos. No âmbito acadêmico, o senhor é constantemente reputado como um exemplo de profissional, além de forte referência na área da Teoria Literária. Considerando sua trajetória pessoal, que conselhos o senhor daria aos jovens pesquisadores que procuram trazer inovações com suas pesquisas acadêmicas?

\section{HANS ULRICH GUMBRECHT}

Gostaria de encorajar os jovens colegas a perseguir suas próprias ideias (quanto mais excêntricas, melhor, até certo ponto) em vez de constantemente indagarem a si mesmos a tediosa pergunta de se o que nós estamos fazendo é suficientemente "profissional". E uma atitude como essa pode ser sinônimo daquilo que me propus a chamar de "pensamento arriscado", isto é, um pensamento que produz alternativas e variações para um pensamento já existente, um pensamento que faz nossa visão de mundo mais complexa e mesmo mais complicada, em vez de prover soluções. 


\title{
THE WORK, THE CONCEPT AND THE MAN: HANS ULRICH GUMBRECHT AND THE "PRODUCTION OF PRESENCE"
}

Translated by:

\author{
Marcelli Caudinni Teixeira Osorio \\ MA student in English Language Literature (Universidade do Estado do Rio de Janeiro, UERJ) \\ marcelliclaudinni@gmail.com \\ Thales Sant'Ana Ferreira Mendes \\ MA student in Brazilian Literature (Universidade do Estado do Rio de Janeiro, UERJ) \\ thales.sanfer@hotmail.com
}

Hans Ulrich "Sepp" Gumbrecht (Wuerzburg, 1948-) helds Albert Guérard Chair as Professor Emeritus in Literature in the Departments of Comparative Literature and of French and Italian and, by courtesy, of German Studies and of Iberian and Latin American Cultures (ILAC) at Stanford University. His researches focuses on the histories of the national literatures in Romance languages (especially French, Spanish, and Brazilian), but also on German literature, besides on the western philosophical tradition (with an emphasis on French and German nineteenth- and twentieth-century texts) and on forms of aesthetic experience in 21st-century everyday culture ${ }^{3}$. In short, his work is quite broad, holding an important repercussion in the academic world, while it transits between various disciplines within the humanities. He has been acknowledged with ten Honorary Doctorates from many universities around the world. He has also held a large number of visiting professorships, such as at the Collège de France, the University of Lisbon, the University of Manchester, and the Catholic University of Rio de Janeiro (PUC-Rio), among others. In Brazil, his most famous book is Production of presence (2004), although he has also written other equally admirable works, such as In 1926: Living at the Edge of Time (1998), In praise of athletic beauty (2006), Unsere breite Gegenwart (2010), Atmosphere, Mood, Stimmung (2012) and After 1945: Latency as Origin of the Present (2013). Kindly, Professor Gumbrecht - who was spending a season in Brazil due to the winter course "'Prose of the World': Diderot's work as a periphery of the Enlightenment (and our present as a contingency universe)", which he was ministering at the House of Rui Barbosa Foundation - has dedicated a little part of his free time to answer our following questions.

\footnotetext{
${ }^{3}$ See his profile on <https://dlcl.stanford.edu/people/hans-ulrich-gumbrecht>.
} 


\section{PALIMPSESTO}

1) Production of Presence is probably your most known work not only in Brazil, but possibly in the academic world. Moreover, it is also a concept strongly associated to your name as a scholar. After more than a decade of its publication, how do you analyze this immediate association between concept and author? What might have occurred so that this concept was highlighted in relation to your set of theoretical productions?

\section{HANS ULRICH GUMBRECHT}

In general and on a much lower level, I have made an experience that Foucault once talked about: the obsessive association of a concept ("presence", in my case) with an author-name can have a strong effect of repetition, in the sense that I am constantly asked to come back to thoughts that were new for me fifteen years ago (Production of presence was first published in 2004). However, I also have to admit that this "presence syndrome" seems to often catch up with me: so, I first think that I am now finally with a new concept, question, concern (stimmung, for example, or "latency"), and then I realize that these apparently "new" concepts do have a genealogical relation to "presence". Altogether, my tendency is rather to escape "presence" than to further cultivate it.

\section{PALIMPSESTO}


2) Looking at the theoretical panorama of the time the concept of "production of presence" was formulated, how do you examine the contributions brought by this concept?

\section{HANS ULRICH GUMBRECHT}

To be honest, I am quite surprised and pleased to see that the resonance has been surprisingly lively. "Presence" seems to have become part of the conceptual horizon within the humanities - nowhere more I believe, than in Brazil.

\section{PALIMPSESTO}

3) New concepts do not happen by chance. Foucault, in "The Discourse on Language" [L'ordre du discours], warned that speeches are constantly creators and debtors of other discourses, even when one is unaware of it. In your works, you discuss the value of learning with the knowledge of the past. How do you particularly see the insertion of your works in certain theoretical frameworks and your affiliation with certain authors and philosophical currents? In short, what essential influences would you highlight in the process of creating the concept of "production of presence"?

\section{HANS ULRICH GUMBRECHT}

Without any doubt (and this should be very visible in the book), Heidegger, the Heidegger "after the turn", was the strongest influence and inspiration for me. More precisely, a specific reading of Heidegger (and I will never know - nor do I care much - 
whether he would have agreed with it) according to which "being" stands for the "the thing in and by itself" that Kant had tried to eliminate from the western philosophical tradition. The importance that Heidegger has had for me by no means implies blindness towards his (biographically evident) Nazism. It is hard but we have to live with the fact that one of the greatest thinkers of the twentieth century was close to its most abject ideology. Today, I believe, the inspiration from that "second" Heidegger partly explains why I want to be part of the return to more "realistic" positions in philosophy and epistemology.

\section{PALIMPSESTO}

4) Researchers are driven by an instinct that impels them to search for innovations that may contribute to their field of study. How does the need to create new concepts arise?

\section{HANS ULRICH GUMBRECHT}

To avoid heroic tones in this answer: my impulse for innovation comes, above all, from a convergence between boredom (I get easily bored when I have to repeat things) and ambition - it matters to me to be read, discussed, criticized.

\section{PALIMPSESTO}

5) Would you say that the creation of new concepts or rereading is always necessary? Do you believe that there are situations in which the search for theoretical innovations is artificial, willing only to create polemics? 


\section{HANS ULRICH GUMBRECHT}

Perhaps I would rather like to say that, from a certain point of view, the creation of new concepts in the humanities is never "necessary". The world outside academia (unfortunately but clearly) can live without our contributions. Within the humanities, by contrast, one can say that innovation is necessary to keep intellectual movement alive. I find it difficult (impossible?), however, to make a systematic claim about better or worse "innovations". Good are those that find resonance - and change the conceptual and epistemological landscape.

\section{PALIMPSESTO}

6) It is not uncommon that theoretical innovations appear against institutions and currents that seek to perpetuate certain traditions, resulting in resistance and distrust. Is it still possible to talk about impacts on literary studies generated by new concepts? How can they unsettle the structures of a critical tradition?

\section{HANS ULRICH GUMBRECHT}

How could innovations not encounter such resistance? This, I believe, is the case for any kind of institution - there is always a tension, sometimes even a struggle, between transformation and inertia. And we have no reason to complain about that.

\section{PALIMPSESTO}


7) Regarding literature in a broader perspective and its diffusion in school spaces, along with the democratization of academic knowledge, what is the importance of the appropriation of new concepts in schools' context and in daily life? Are there any efficient methods to achieve this goal?

\section{HANS ULRICH GUMBRECHT}

I do not believe in "methods" that could guarantee attention and resonance for new ideas produced in the humanities - and if they existed, I would probably not use them because I find any kind of "self-promotion" in this sense very embarrassing. We do work under quite privileged positions to produce new ideas, arguments, and concepts and we should not try to control their reception and resonance. In my case, I think I have once found such resonance outside the academic institution, and this was with my book In praise of athletic beauty as a proposal for an understanding of spectator sports as an object of aesthetic experience.

\section{PALIMPSESTO}

8) Lives devoted to scientific research may suffer changes that are beyond researchers' wishes since academic institutions are also spaces inhabited by political and social struggles. From your viewpoint, considering power relations involved in this field and the distribution of symbolic capital, what are the obstacles for the expansion, recognition and even application of some concepts in Literary Theory?

\section{HANS ULRICH GUMBRECHT}


I have always had the suspicion that to be "resisted" and even "repressed" by political powers is a dream many of our colleagues are dreaming because this would mean that politicians take us seriously - and even fear us. The opposite is the case though - they are normally not interested in what we are writing and doing. The only resistance that I have personally found was from inside academia. The publisher who first came out with the original version of "production of presence" did fear that the book could provoke some resistance from "deconstruction" as a then quite popular and dominant philosophical discourse.

\section{PALIMPSESTO}

9) Professors always have something to bestow on their students. In the academy, you are constantly referred as an example of professional and also as a renowned Literary Theory scholar. Considering your personal path, what advice would you give to young researchers who aim to contribute with innovations within their academic researches?

\section{HANS ULRICH GUMBRECHT}

I would like to encourage young colleagues to pursue their own ideas (the more eccentric the better, to a certain degree) instead of constantly asking the tedious question of whether what we are doing is "professional" enough. And such an attitude may be synonymous with what I have proposed to call "riskful thinking", that is a thinking that produces alternatives and variations to already existing thought, a thought that makes our view of the world more complex and often even more complicated - instead of providing solutions. 